\title{
IMPLEMENTASI TUGAS NAZHIR DALAM PENGELOLAAN HARTA WAKAF BERDASARKAN UNDANG-UNDANG NO. 1 TAHUN 2014 DI KECAMATAN KAUR UTARA KABUPATEN KAUR
}

\author{
Nilda Susilawati, Ita Guspita \\ IAIN Bengkulu, Indonesia \\ Email : nilda79@iainbengkulu.ac.id
}

\begin{abstract}
The purpose of this study was to determine the implementation of Nazhir duties in the management of waqf property, and Nazir constraints in the management of waqf property. Using a field method with a qualitative approach with primary and secondary data sources by conducting interviews with 18 Nazir who became informants. From the results of this study note that: (1) Nazir has not been maximized in carrying out his duties in accordance with the mandate in Law Number 41 of 2004, namely: administering waqf assets, managing waqf assets according to their purpose and designation, supervising and protecting the properties of waqf, and reporting the implementation of waqf assets. his duty to the Indonesian Waqf Board. Only the administration of waqf assets has been done but other tasks have not been carried out, and only 5 nazhirs have been implemented from the 18 nazhirs. : lack of Nazir knowledge in managing waqf assets, lack of socialization and guidance from related parties such as KUA and BWI, management costs are constrained.
\end{abstract}

Keywords: Implementation, Nazhir, Waqf

Abstrak: Tujuan dari penelitian ini untuk mengetahui implementasi tugas nazhir dalam pengelolaan harta wakaf, dan kendala nazhir dalam pengelolaan harta wakaf. Menggunakan metode lapangan dengan pendekatan kualitatif dengan sumber data primer dan sekunder dengan melakukan wawancara kepada 18 nazhir yang menjadi informan .Dari hasil penelitian ini diketahui bahwa: (1) nazhir belum maksimal dalam melaksnakan tugasnya sesuai amanah dalam Undang-Undang Nomor 41 Tahun 2004 yaitu: melakukan pengadministrasian harta wakaf, mengelola harta wakaf sesuai tujuan dan peruntukannya, mengawasi dan melindungi harta wakaf, serta melaporkan pelaksanaan tugasnya kepada Badan Wakaf Indonesia. Yang sudah dilakukan baru pengadministrasian harta wakaf namun tugas lainnya belum dilaksanakan, dan yang sudah mengimplementasikan tugas tersebut hanya 5 orang nazhir dari ke 18 nazhir tersebut, dalam pengelolaan harta wakaf secara produktif belum dilakukan(2) kendala yang dialami oleh nazhir dalam pengelolaan harta wakaf yaitu: kurangnya pengetahuan nazhir dalam pengelolaan harta wakaf, kurangnya sosialisasi dan pembinaan dari pihah-pihak yang terkait seperti KUA dan BWI, terkendalanya biaya pengelolaan.

Kata Kunci: Implementasi, Nazhir, Wakaf

\section{A. PENDAHULUAN}

Tugas nazhir dalam Undang-

Undang Nomor 41 Tahun 2004 Pasal 11, ditentukan bahwa tugas nazhir adalah melakukan pengadministrasian harta wakaf, mengelola dan mengembangkan harta benda wakaf sesuai dengan tujuan, fungsi dan peruntukannya, mengawasi dan melindungi harta benda wakaf, melaporkan pelaksanaan tugas kepada Badan Wakaf Indonesia (BWI). ${ }^{1}$

Pelaksanaan tugas nazhir dilakukan setelah wakif melaksanakan ikrar wakaf, Nazhir memiliki peranan terhadap benda wakaf tersebut. Baik dari proses administrasinya, maupun pengelolaanya, sehingga tujuan dan fungsi harta benda wakaf dapat tercapai sesuai denga

\footnotetext{
${ }^{1}$ Pasal 11 Undang - Undang Nomor 41 Tahun
} 2004 Tentang Wakaf 
peruntukannya. Yang lebih utama lagi yaitu tugas nazhir terhadap pemanfaatan hasil pengelolaan wakaf untuk kepentingan masyarakat. Karena tugas nazhir menyangkut harta benda yang manfaatnya bisa dinikmati oleh masyarakat, maka jabatan nazhir harus diberikan kepada orang yang mampu untuk melaksanakan tugas tersebut.

Secara geografis Kecamatan Kaur Utara terletak di sebelah barat pegunungan bukit barisan, termasuk dalam wilayah administrasi Kabupaten Kaur, Provisi Bengkulu, Indonesia, berjarak $40 \mathrm{~km}$ dari Ibukota Kabupaten Kaur dan 230 km dari Provinsi Bengkulu

Di Kecamatan Kaur Utara, sebagian besar masjid, pesantren, madrasah dan tempat pemakaman umum (TPU) didirikan di atas tanah wakaf sebanyak 12 masjid, 4 Tempat Pemakaman Umum, 1 SMP, dan 1 lahan kosong yang rencananya akan digunakan untuk pembangunan masjid, dari 18 tanah wakaf tersebut yang sudah memiliki Akta Ikrar Wakaf berjumlah 4 harta wakaf dalam bentuk masjid, dan yang belum memiliki Akta Ikrar Wakaf berjumlah 14 harta wakaf dengan rincian, 4
Tempat Pemakaman, 8 Masjid, 1 SMP, dan 1 tanah kosong. ${ }^{2}$

\section{B. LANDASAN TEORI}

\section{Konsepsi Wakaf}

Kata "wakaf' atau "waqf' berasal dari bahasa arab "waqafa" yang artinya "menahan". Kata "waqafa (fiil madi)yaqifu(fiil mudari) sama artinya dengan "habasa-yahbisu-tahbisan" artinya mewakafkan. $^{3}$

Disebut menahan karena wakaf ditahan dari kerusakan, penjualan, penghibahan maupun diwariskan dan semua tindakan yang tidak sesuai dengan tujuan wakaf. Selain itu dikatakan menahan juga karena manfaat dan hasilnya ditahan dan dilarang bagi siapapun selain dari orang yang berhak atas wakaf tersebut.

Secara bahasa kata wakaf (alwaqf) berarti al-habs yang secara bahasa Indonesia diartikan menahan. Hal ini sebagaimana perkataan seseorang waqafa-yaqifu-waqfan, artinya habasayahbisu-habsan. Kata al-waqfu bila dijamakkan menjadi al-awqaf dan wuquf, sedangkan bentuk kata kerjanya

\footnotetext{
${ }^{2}$ Irlianuddin.Kepala KUA Kecamatan Kaur Utara. Wawancara Tanggal 16 Oktober 2018

${ }^{3}$ Ahmad Warson Munawir, Kamus AlMunawir Arab Indonesia, (Surabaya: Pustaka Progresif, 2002), hlm. 1576
} 
(fi'il) adalah waqafa. Menurut bahasa, waqafa berarti menahan atau mencegah, misalnya kata waqaftu 'ani al-sairi, yang bermakna "saya menahan diri dari berjalan”. Dalam peristilahan syara', wakaf adalah sejenis pemberian yang pelaksanaannya dilakukan dengan jalan menahan (pemilikan) asal (tahbisu alashli), lalu menjadikan manfaatnya berlaku umum. ${ }^{4}$

Kata al-habs bermakna menahan harta dan memanfaatkan hasilnya di jalan Allah, atau ada juga yang bermaksud menghentikan seperti yang disebutkan di atas. Maknanya di sini, menghentikan manfaat keuntungannya dan diganti untuk amal kebaikan sesuai dengan tujuan wakaf. Menghentikan segala aktifitas yang pada mulanya diperbolehkan terhadap harta ('ain benda itu), seperti menjual, menghibahkan, mewariskan, mentransaksikan, maka setelah dijadikan harta wakaf hanya untuk keperluan agama semata bukan untuk keperluan si waqif atau individual lainnya. ${ }^{5}$ Para ahli fiqih mendifinisikan

${ }^{4}$ Muhammad Jawwad Mughniyah, Fiqh Lima Mazhab, Cet. Ke-I (Jakarta: Basrie Press, 1997), hlm.383

${ }^{5}$ Abdul Halim, Hukum Perwakafan Di Indonesia (Jakarta: Ciputat Press, 2005), hlm. 8 wakaf dengan pandangan yang berbedabeda dibawah ini akan dijelaskan pengertian wakaf. Menurut Imam Abu Hanifah Wakaf adalah menahan suatu benda yang menurut hukum, tetap milik si wakif dalam rangka mempergunakan manfaatnya untuk kebajikan. Berdasarkan definisi itu maka pemilik harta wakaf tidak lepas dari wakif, bahkan ia dibenarkan menariknya kembali dan ia boleh menjualnya. Menurut mahab Hanafi Jika si wakif wafat, maka harta tersebut menjadi harta warisan buat ahli warisnya. Jadi yang timbul dari wakaf hanyalah "menyumbangkan manfaat". Karena itu mazhab hanafi mendefinisikan wakaf adalah : "Tidak sebagai hak milik, dengan menyedekahkan manfaatnya kepada suatu pihak kebajikan (social), baik sekarang maupun akan datang". Sedangkan menurut Mazhab Maliki berpendapat bahwa wakaf itu tidak melepaskan harta yang diwakafkan dari kepemilikan wakif, namun wakaf tersebut mencegah wakif melakukan tindakan yang dapat melepaskan kepemilikannya atas harta tersebut kepada yang lain dan wakif berkewajiban menyedekahkan 
manfaatnya serta tidak boleh lagi menarik kembali wakafnya. ${ }^{6}$

Menurut undang-undang No.41 Tahun 2004 pengertian wakaf adalah "wakaf diartikan dengan perbuatan hukum wakif untuk memisahkan dan/atau menyerahkan sebagian harta benda miliknya untuk dimanfaatkan selamanya atau untuk jangka waktu tertentu sesuai dengan kepentingannya guna keperluan ibadah dan/atau kesejahteraan umum menurut syariah.

Wakaf dikatakan sah apabila sudah terpenuhi rukun dan syarat wakaf yaitu: wakif, dengan syarat orang yang mewakafkan (wakif) disyaratkan memiliki kecakapan hukum atau kamalul ahliyah (legal competent) dalam membelanjakan hartanya. Cakapan bertindak meliputi kriteria merdeka, berakal sehat, balig dan tidak berada dibawah pengampuan (boros atau lalai). Kedua, mauquf bih' dengan syarat harta yang diwakafkan harus mutaqawwam, diketahui dengan baik ketika akan diwakafkan, milik wakif, harta bukan milik bersama dan sifatnya kekal serta bisa dimanfaatkan secara

\footnotetext{
${ }^{6}$ Sumuran Harahap, Fiqh Wakaf, (Jakarta : Dapertemen Agama Republik Indonesia, 2007), hlm.3
}

terus menerus. ${ }^{7}$ Ketiga, Muaquf'alaih (orang yang menerima peruntukan wakaf atau nazhir) dengan syarat harus dinyatakan dengan jelas dan tegas ketika mengikrarkan wakaf tentang peruntukan wakaf tersebut. Keempat, ikrar wakaf, Tentang shigat wakaf ini merupakan rukun wakaf yang disepakati oleh jumhur fuqaha.Tanpa adanya ikrar wakaf, para fuqaha menganggap wakaf belum sempurna dilaksanakan.Yang dimaksud dengan ikrar wakaf adalah pernyataan yang merupakan penyerahan barang-barang wakaf kepada nazhir untuk dikelola sebagaimana yang diharapkan oleh pemberi wakaf.

Secara umum pembagian wakaf menjadi dua:

a. Wakaf Alaih

Wakaf ahli adalah wakaf yang hasilnya diperuntukan untuk orang tertentu yang umumnya terdiri atas keluarga, anggota keluarga atau keturunan siwaqif. Oleh karena itu wakaf ini sering disebut dengan wakaf zurri atau wakaf untuk anggota keluarga.

${ }^{7}$ Abdul Manan, Aneka Masalah Hukum Perdata Islam di Indonesia, cet.2 (Jakarta : Kecana, 2008), hlm. 240 
Dalam satu sisi,wakaf ahli ini baik sekali karena waqif akan mendapatkan dua kebaikan, yaitu kebaikan amal ibadah waqafnya ,juga kebaikan dari silaturrahminya dengan orang yang diberi amanah wakaf. Akan tetapi disisi lain, wakaf ahli ini sering menimbulkan masalah, seperti bagaimana kalau anak yang ditunjuk sudah tidak ada lagi keturunan, siapa yang berhak. Mengambil manfaat dari harta tersebut.Lebih-lebih pada saat akad wakafnya tidak disertai dengan bukti tertulis yang dicatatkan kepada Negara.

\section{b. Wakaf khairi}

Wakaf khairi adalah wakaf yang secara tegas untuk kepentingan agama (keagamaan) atau kemasyarakatan (kepentingan umum. Wakaf dalam bentuk seperti ini jelas lebih banyak manfaatnya dari pada wakaf ahli, karena tidak terbatasnya orang atau kelompok yang bisa mengambil manfaat, dan ini yang sesungguhnya semangat yang diajarkan oleh wakaf itu sendiri.

Harta benda wakaf dalam Pasal 16 Undang-Undang Nomor 41 Tahun 2004 tentang wakaf dibagi menjadi dua, pertama benda tidak bergerak meliputi: 1) Hak atas tanah sesuai dengan peraturan perundangundangan yang berlaku baik yang sudah maupun yang belum terdaftar.

2) Bangunan atau bagian bangunan yang berdiri di atas tanah. 3)Tanaman dan benda lain yang berkaitan dengan tanah. 4) Hak milik atas satuan rumah susun sesuai dengan ketentuan peraturan perundang-undangan yang berlaku; 5) Benda tidak bergerak lain sesuai dengan ketentuan syariah dan peraturan perundang-undangan yang berlaku.

Kedua, benda bergerak merupakan harta benda yang tidak bisa habis karena dikonsumsi, meliputi uang, logam, surat berharga, kendaraan, hak atas kekayaan intelektual, hak sewa dan benda bergerak lain sesuai dengan ketentuan syariah dan peraturan perundang-undangan yang berlaku. ${ }^{8}$

\section{Perubahan Status dan Pergantian Benda Wakaf}

Tentang perubahan status, pergantian benda dan tujuan wakaf,

\footnotetext{
${ }^{8}$ Undang-Undang Nomor 41 Tahun 2004
} Tentang Wakaf, (Pasal 16 Harta Benda Wakaf) 
sangat ketat peraturannya dalam madzhab Syafi'I. Namun demikian, berdasarkan keadaan darurat dan prinsip maslahat, dikalangan para ahli hukum (fikih) Islam mazhab lain, perubahan itu dapat dilakukan. Ini didasarkan pada pandangan agar manfaat itu tetap terus berlangsung sebagai shadaqah jariah, tidak mubazir karena rusak, tidak berfungsi lagi dan sebagai sebagainya. Dengan perubahan itu, status benda itu sebagai harta wakaf pada hakikatnya tidaklah berubah. Misalnya dengan menukar tempat tanah wakaf, status tanah wakaf tidaklah berubah karena pertukaran tempat itu seakan-akan tanah wakaf itu dipindahkan ketempat lain. Ini mungkin terjadi sebab statusnya ditanah asal tidak dapat dipertahankan lagi karena tidak dapat dimanfaatkan sebagai tanah wakaf. 9

Dalam pasal 40-41 UndangUndang Nomor 41 Tahun 2004 tentang perubahan status harta benda wakaf pada pasal 40 harta benda wakaf yang sudah diwakafkan dilarang dijadikan jaminan, disita, dihibahkan, dijual,

${ }^{9}$ Muhammad Daud Ali, Sistem Ekonomi Islam: Zakat dan Wakaf, (Jakarta: Universitas Indonesia (UIPress, 2012), hlm. 93 diwariskan ditukar dan dialihkan dalam bentuk hak lainnya. ${ }^{10}$

Perubahan harta wakaf selanjutnya dijelaskan pada pasal 41 bahwa dikecualikan apabila harta benda wakaf yang telah diwakafkan digunkan untuk kepentigan umum sesuai dengan rencana umum tata ruang (RUTR) berdasarkan ketentuan peraturan perundang-undsngsn yang berlaku dan tidak bertentangan dengan syariah. Pelaksanaannya dapat dilakukan setelah memperoleh izin tertulis dari menteri atau persetujuan Badan Wakaf Indonesia, harta benda wakaf yang sudah diubah statusnya wajib ditukar dengan harta benda yang manfaat dan nilai tukar sekurang-kurangnya sama dengan harta benda wakaf semula dan selanjunya perubahan harta wakaf tersebut di atur dalam peraturan pemerintah.

\section{Tugas dan Tanggung Jawab Nazhir}

Dalam Undang-Undan Nomor 41 Tahun 2004 Pasal 11, ditentukan bahwa tugas nazhir sebagai berikut :

a. Melakukan pengadministrasian harta benda wakaf.

\footnotetext{
${ }^{10}$ Undang-undang Nomor 41 Tahun 2004 Tentang Wakaf (Pasal 40-41)
} 
b. Mengelola dan mengembangkan harta benda wakaf sesuai dengan tujuan, fungsi dan peruntukannya.

c. Mengawasi dan melindungi harta benda wakaf

d. Melaporkan pelaksanaan tugas kepada Badan Wakaf Indonesia (BWI).

Adapun jenis-jenis nazhir yaitu:

a. Nazhir individu/perorangan, dengan syarat Warga Negara Indonesia, beragama Islam, dewasa, amanah, dan mampu secara jasmani dan rohani dan tidak terhalang melakukan perbuatan hukum ${ }^{11}$

b. Nazhir organisasi, apabila memenuhi persyaratan, yaitu pengurus organisasi memenuhi persyaratan Nazhir perorangan dan organisasinya yang bergerak dibidang sosial, pendidikan dan kemasyarakatan

c. Nazhir badan hukum, dengan syarat pengurus badan hukum memenuhi persyaratan nazhir perseorangan, badan hukum Indonesia dibentuk berdasarkan perundang-undangan dan bergerak dalam bidang sosial,

${ }^{11}$ Saekan Erniati Effendi, Kompilasi Hukum Islam di Indonesia, (Surabaya : Arkola Offiset, 1997), hlm. 141 kemasyarakatan

dan/atau

keagamaan.

Untuk melaksanakan tugas sebagai nazhir, maka secara personal seorng nazhir harus memiliki kemampuan dalam moral, manajemen dan bisnis. Pertama, moral berupa pemahaman tentang hukum wakaf dan ZIS, baik dalam bidang tinjan hukum syari'ah maupun perundang-undangan RI, jujur, amanah dan adil serta mempunyai kecerdasan, baik emosional maupun spiritual. Kedua, memiliki kemampuan manajemen berupa kapasitas dan kapabilitas yang baik dalam leadership, visioner, kecerdasan yang baik secara intelektual, sosial dan pemberdayaan, dan profesional dalam pengelolaan harta, dan ketiga memiliki kemampuan bisnis berupa pengalaman dan atau siap untuk dimagangkan, dan memiliki ketajaman melihat peluang usaha sebagaimana layaknya entrepreneur.

\section{Hak dan Kewajiban Nazhir}

Nazhir yang bertugas sebagai pemegang amanat untuk memelihara, mengurus dan mengelola harta wakaf, sudah sepantasnya mempunyai kewajiban-kewajiban yang harus dilaksanakannya, selain juga 
mempunyai hak-hak yang harus

diterimanya atas tugas-tugas

tersebut.Kewajiban nazhir meliputi hal-

hal yang berkaitan dengan

pemeliharaan, pengurusan, dan

pengawasan harta wakaf serta hasilhasilnya. ${ }^{12}$

Nazhir yang bertugas sebagai pemegang amanat untuk memelihara, mengurus dan mengelola harta wakaf, sudah sepantasnya mempunyai kewajiban-kewajiban yang harus dilaksanakannya, selain juga mempunyai hak-hak yang harus diterimanya atas tugas-tugas tersebut. Kewajiban nazhir meliputi hal-hal yang berkaitan dengan pemeliharaan, pengurusan, dan pengawasan harta wakaf serta hasil-hasilnya. ${ }^{13}$

Nazhir mempunyai kewajiban mengurus dan mengawasi harta kekayaan wakaf dan hasilnya meliputi :

a. Menyimpan lembar salinan Akta Ikrar Wakaf (AIW) sebagai bukti yang akan digunakan untuk berbagai kepentingan.

b. Memelihara dan memanfaatkan tanah wakaf

\footnotetext{
${ }^{12}$ Suparman Usman, Perwakafan Di Indonesia (Serang : Darul Ulum Press, 1994), hlm. 99

${ }^{13}$ Suparman Usman, Perwakafan di Indonesia, (Serang : Darul Ulum Press, 1994), hlm.99
}

c. Berusaha meningkatkan hasil wakaf

d. Menyelenggarakan pembukuan dan administrasi perwakafan dengan memelihara buku catatan tanah wakaf, serta buku catatan tentang penggunaan hasil tanah wakaf. ${ }^{14}$

Nazhir wakaf berwenang melakukan segala tindakan yang mendatangkan kebaikan dengan senantiasa memperhatikan syarat-syarat yang telah ditentukan.Misalnya, jika wakaf berupa tanah, nazhir berhak menanaminya dengan tanaman yang dianggapnya baik dan memberikan hasil.

Nazhir berhak mendapatkan upah untuk jerih payahnya mengurus harta wakaf, selama ia melaksanakan tugasnya dengan baik. Besarnya sesuai dengan ketentuan, bisa sepersepuluh atau seperdelapan dari hasil tanah yang diwakafkan, atau sejumlah yang pantas diterima oleh nazhir asalkan tidak melebihi sepuluh persen (10\%) hasil bersih tanah wakaf. Sebagai pemegang amanah pada dasarnya nazhir tidak dibebani oleh resiko yang terjadi atas tanah wakaf, kecuali dapat dibuktikan bahwa kerusakan atau kerugian yang

\footnotetext{
${ }^{14}$ Muhamad Daud Ali, Sistem Ekonomi Islam Zakat dan Wakaf...hlm.114
} 
terjadi itu karena kelalaian atau kesengajaan.

Mengingat salah satu tujuan wakaf ialah menjadikannya sebagai sumber dana yang produktif, tentu memerlukan Nazhir yang professional dan bertanggungjawab. Apabila Nazhir tidak tidak mampu melaksankan tugastugasnya, maka Qadhi (pemerintah) wajib menggantinya dengan tetap menjelaskan alasannya.

Fleksibelitas persyaratan nazhir itu tergantung kebutuhan dilapangan. Kalau selama ini nazhir wakaf perseorangan masih dipakai dan ternyata dalam pelaksanaannya tidak memberikan peran yang baik dalam pengelolaan wakaf, maka persyaratan nazhir harus berupa badan hukum menjadi keniscayaan agar dapat memberdayakan benda-benda wakaf secara optimal.

Pengangatan dan pemberhentian nazhir pada hakikatnya dapat dilakukan oleh siapa saja, asalkan memenuhi syarat-syarat untuk menjadi nazhir. Menurut fiqh, seorang wakif bisa menunjuk dirinya sendiri atau orang lain untuk menjadi nazhir, namun jika wakif tidak menunjuk siapapun untuk menjadi nazhir, maka yang bertindak sebagai nazhir adalah wali dari tempat wakaf trsebut. Tetapi pada saat ini seharusnya yang menjadi nazhir diangkat dan diberhentikan oleh Badan Wakaf Indonesia selaku lembaga yang mengurus tentang wakaf. ${ }^{15}$

Nazhir merupakan faktor penting dalam pengelolaan wakaf, berkembang dan tidaknya harta wakaf berada di tangan nazhir. Nazhir memiliki tugas yang cukup besar dalam mengelola harta wakaf, karena itu penting menajemen dan visi bisnis dari seorang nazhir dalam mengelola wakaf. Ketidakpengetahuan nazhir akan tugas dan tanggung jawab dalam mengelola wakaf menjadikan manfaat harta wakaf tidak dapat dirasakan secara maksimal oleh masyarakat. Kemampuan profesional nazhir dalam mengelola wakaf harus didukung oleh pengetahuan yang mendalam tentang agama dan manajemen diharapkan dapat mengembangkan wakaf dengan baik.

Tidak bisa dipungkiri, mayoritas nazhir wakaf di indonesia kurang profesional dalam mengelola harta wakaf yang diamanatkan kepadanya. Umumnya mereka bekerja sambilan. Mereka memiliki pekerjaan tetap seperti

\footnotetext{
${ }^{15}$ Faisal Haq, Wakaf dan Pewakafan di Indonesia, (Pasuruan : Garoeda Indah, 1994), hlm.56
} 
Pegawai Negeri Sipil, Petani, Pedagang, dan sebagainya yang harus diutamakan disamping tugas sebagai nazhir. Kenyataan ini menggambarkan bahwa profesi nazhir bukanlah yang diharapkan dalam masyarakat. Nazhir dipilih bukan atas dasar profesional, tetapi karena ketokohan, kerabat dekat wakif, atau orang kepercayaan wakif. ${ }^{16}$

Akibat tidak keprofesionalan nazhir, banya harta wakaf yang tidak member manfaat kepada masyarakat, bahkan banyak harta wakaf yang dijadikan warisan sanak keluarga nazhir, atau dipersengketakan oleh ahli waris wakif. Realita ini kadang menjadi kendala bagi calon wakif sehingga ragu untuk mewakafkan hartanya. Untuk itu nazhir wakaf harus membuktikan terlebih dahulu kepada masyarakat, bahwa amanah mengelola harta wakaf bisa berhasil dan mendatangkan manfaat kepada masyarakat sehingga calon wakif dapat tergerak hatinya untuk mewakafkan sebagian hartanya. Hal ini harus dibuktikan dengan loyalitas,

\footnotetext{
${ }^{16}$ Direktorat Pengembangan Zakat dan Wakaf, Nazhir Profesional dan Amanah, (Jakarta : Ikhlas Beramal, 2005), hlm. 76
}

keikhlasan dan kehati-hatian dalam pengelolaan harta wakaf. ${ }^{17}$

Dalam rangka memelihara dan melestarikan manfaat wakaf, keberadaan nazhir sangat dibutuhkan, bahkan menempati posisi sentral. Sebab nazhir mempunyai tanggung jawab dan kewajiban memelihara, menjaga mengembangkan harta wakaf, serta menyalurkan hasilnya. Banyak pengelolaan wakaf yang tidak efektif dan belum mendatangkan manfaat yang maksimal kepada masyarakat. Profesionalisme nazhir wakaf menjadi ukuran yang paling penting dalam pengelolaan harta wakaf.

Seorang nazhir profesional dalam mengelola harta wakaf harus mengacu pada prinsip-prinsip modern. Kata profesional berasal dari kata profesi, berarti pekerjaan, dilakukan dengan mengandalkan keahlian, keterampilan yang tinggi dan memelihara komitmen yang kuat. Ada beberapa ciri atau karakteristik profesional, yaitu:

a. Mempunyai keahlian dan keterampilan khusus untuk dapat menjalankan pekerjaan dengan baik.

b. Adanya komitmen moral yang tinggi

\footnotetext{
${ }^{17}$ Direktorat Pengembangan Zakat dan Wakaf, Nazhir Profesional..., hlm. 77
} 
Untuk profesi pelayanan sosial, komitmen dituangkan dalam kode etik profesi. Etika ini merupaka peraturan yang harus dijalankan dalam melaksankan pekerjaan. Kode etik profesi ini ditujukan untuk melindungi masyarakat dari kerugian dan kelalaian, baik disengaja maupun tidak disengaja, dan ditujukan untuk melindungi profesi tersebut dari perilaku-perilaku yang tidak baik.

c. Orang yang profesional biasanya hidup dari profesi yang dijalankannya. Ia dibayar dengan gaji yang layak sebagai kensekuensi dari pengerahan seluruh tenaga, fikiran, keahlian dan keterampilan.

d. Pengabdian kepada masyarakat, adanya komitmen moral yang tertuang dalam kode etik profesi ketika orang-orang yang mengemban suatu profesi lebih mengutamakan kepentingan masyarakat daripada kepentingan dirinya.

e. Legalisasi keizinan. Untuk profesi yang menyangkut kepentingan orang banyak yang terkait dengan nilainilai kemanusiaan, maka profesi tersebut haruslah profesi yang sah dan diizinkan. ${ }^{18}$

Seorang profesional adalah orang yang melakukan pekerjaan dengan keahlian dan keterampilan yang tinggi, serta mempunyai komitmen yang tinggi atas pekerjaannya. Seorang nazhir wakaf dianggap profesional jika ia melakukan pekerjaan karena ia ahli dibidang itu, mengerahkan waktu, fikiran, dan tenaga untuk pekerjaan tersebut. Komitmen pribadi inilah yang melahirkan tanggungjawab yang besar dan tinggi atas pekerjaannya. Seorang nazhir yang profesional dalam mengelola harta wakaf tidak hanya sekedar mengisi waktu luang atau pekerjaan sampingan, akan tetapi, dia sadar dan yakin bahwa pekerjaannya menyatu dengan dirinya. Dia berkembang seiring dengan perkembangan dan kemajuan pekerjaannya.

Untuk itu, dalam rangka meningkatkan kemampuan nazhir, diperlukan sistem manajemen sumber daya manusian yang bagus, agar dapat 
mencapai tujuan yang telah

direncanakan. Tujuannya yaitu:

a. Meningkatkan dan mengembangkan pengetahuan, kemampuan, dan keterampilan nazhir dalam rangka membangun kemampuan manajerial yang tangguh, profesional dan bertanggungjawab.

b. Membentuk sikap dan prilaku nazhir wakaf sesuai dengan akhlakul karimah.

c. Menciptakan pola fikir yang sama dalam memahami dan menerapkan pola pengelolaan wakaf, baik dari segi undang-undang wakaf maupun teknis manajerial, sehingga lebih mudah melakukan pengendalian.

d. Mengajak para nazhir wakaf untuk memahami tata cara pengelolaan yang lebih berorientasi pada kepentingan pelaksanaan syariat islam secara lebih luas sehingga wakaf bisa menjadi salah satu elemen penting dalam menunjang penerapan sistem ekonomi syariah secara terpadu.

Untuk mencapai hal ini, diperlukan upaya nazhir wakaf agar mereka dapat menjalani tugas-tugas kenazhiran secara produktif dan berkualitas. Upaya pembinaan yang harus dilakukan berdasarkan standar pola manajemen terkini, yakni melalui pendidikan formal, seperti sekolah kejujuran, maupun sekolah umum untuk mencetak calon-calon sumber daya nazhir yang siap melaksankan tugas sebagai nazhir. Misalnya, sekolah pertanian untuk calon nazhir yang dipersiapkan mengelola tanah wakaf yang berupa lhan pertanian, perkebunan dan lain-lain. Lalu didirikan juga sekolah ekonomi untuk mengelola tanah wakaf untuk area perdagangan dan sebagainya. Kemudian, dilakukan pendidikan nonformal berupa kursus, pelatihan kenazhiran terkait manajerial organisasi atau keterampilan berupa teknik pengelolaan pertanian, perdagangan, pemasaran dan sebagainya. $^{19}$

Nazhir yang ada ditingkatkan secara kemampuannya baik melalui pelatihan yang intensif, maupun bimbingan. Ini menghasilkan nazhir yang memiliki kemampuan dalam memegang tanggung jawabnya sebagai pengelola dan pengembang harta wakaf. Para nazhir dalam bekerja harus

${ }^{19}$ Direktorat Pengembangan Zakat dan Wakaf, Nazhir Profesional dan Amanah, (Jakarta : Ikhlas Beramal, 2005), hlm. 78 
meletakan prinsip-prinsip, amanah, transparan, akuntabilitas, dan inovatif. Selain itu, sistem operasional lembaga pengelola wakaf juga harus mengakomodasikan kebutuhan para nazhir, sehingga para nazhir dapat memberikan karyanya secara maksimal dalam membangun lembaga pengelolaan harta wakaf.

Pada Undang-undang No. 41 tahun 2004, pasal 42 dijelakan bahwa nazhir wajib mengelola dan mengembangkan harta wakaf sesuai dengan tujuan dan peruntukannya. Sedanngkan dalam pasal 43 pengelolaan dan pengembangan harta benda wakaf dilaksanakan sesuai prinsip syariah, pengelolaan dan pengembangan harta wakaf dialakukan secara produktif, dalam pengelolaan dan pengembangan harta benda wakaf diperlukan penjamin, maka menggunakan lembaga penjamin syariah.

Jika nazhir tidak melaksanakan tugasnya atau melanggar ketentuan dalam pengelolaan dan pengembangan harta benda wakaf sesuai dengan peraturan yang berlaku maka Badan Wakaf Indonesia berhak memberhentikan nazhir yang bersangkutan.

\section{METODE PENELITIAN}

Jenis penelitian yang digunakan dalam penelitian ini adalah penelitian lapangan (fiel research) yaitu penelitian yang dilakukan langsung kelapangan guna memperoleh data yang lengkap dan valid mengenai penelitian ini, pendekatan yang digunakan adalah deskriptif kualitatif yaitu pendekatan yang ditujukan untuk menjelaskan fenomena yang sedang terjadi dimasyarakat berupa data-data dengan membahas objek yang diteliti tentang tugas nazhir dalam pengelolaan harta wakaf di Kecamatan Kaur Utara Kabupaten Kaur.

Observasi digunakan untuk mengamati situasi awal yang ada di Kecamatan Kaur Utara, selain itu juga menggunakan wawancara dalam bentuk wawancara terstruktur atau terperinci, dalam wawancara ini peneliti menyiapkan sendiri masalah dan pertanyaan-pertanyaan yang akan diajukan. Pertanyaaanpertanyaan itu mengacu pada seputar masalah peran nazhir dalam pengelolaan harta wakaf, dan pelacakan dokumentasi terkait data harta wakaf dan sistem pengelolaan harta wakaf yang telah dilakukan oleh nazhir. Teknik analisis data dalam penelitian ini mengikuti konsep Miles dan Huberman. Miles dan Huberman mengungkapkan bahwa aktifitas dalam 
analisis data kualitatif dilakukan secara interaktif dan berlangsung secara terusmenerus pada setiap tahapan penelitian sampai dengan tuntas. $^{20}$ Tahapan dalam analisis data yaitu reduksi data, yaitu proses pemilihan, pemusatan perhatian pada penyederhanaan, pengabstrakan, dan informasi data mentah atau data kasar yang muncul dari catatan-catatan tertulis dilapangan. Penyajian data, yaitu penyusunan informasi yang kompleks kedalam suatu bentuk yang sistematis, sehingga menjadi lebih efektif dan sederhana serta memberikan kemungkinan danya penarikan kesimpulan data dan pengambilan tindakan. Penarikan Kesimpulan, yaitu merupakan tahap akhir dalam proses analisis data, pada bagian ini peneliti mengutarakan kesimpulan dari data-data yang telah diperoleh dari wawancara dan dokumentasi.

\section{HASIL DAN PEMBAHASAN}

\section{Pelaksanaan tugas nazhir di} Kecamatan Kaur

Informan dalam penelitian ini berjumlah 20 orang yang merupakan nazhir dari harta wakaf berupa sarana ibadah atau mesjid, sarana pendidikan,

\footnotetext{
${ }^{20}$ Sugiyono, memahami Penelitian Kualitatif, (Bandung: Alfabeta, 2014), hlm. 345
}

tempat pemakaman umum, dan tanah yang belum dikelola.

Harta wakaf yang berupa sarana ibadah atau mesjid berjumlah 12 mesjid, sarana pendidikan berupa sekolah SMP berjumlah 1 sekolah, pemakaman umum berjumlah 4 lahan dan 1 buah tanah kosong yang belum dimanfaat dan dikembangkan. Dan yang telah memiliki Akta Ikrar Wakaf dengan rincian:

a. Masjid yang belum memiliki Akta Ikrar Wakaf berjumlah 8 Masjid dan yang sudah memiliki Akta Ikrar Wakaf berjumlah 4 masjid

b. Tempat Pemakaman Umum berjumlah 4 TPU yang semuanya belum mempunyai Akta Ikrar Wakaf

c. Bangunan lain seperti Sekolah Menengah Pertama (SMP) berjumlah 1 Sekolah.

d. 1 lahan kosong yang akan di manfaatkan untuk pembangunan masjid.

e. Yang memiliki potensi pengelolaan cukup besar berjumlah 5 harta wakaf yang terdiri dari masjid jamiatul muslimin, masjid Al-Muqaromah, masjid Mujahidin, SMP langgar Tarbiah, dan 1 wakaf berbentuk lahan kosong. 
Dari hasil wawancara dengan nazhir wakaf yang menjadi informan dalam penelitian ini didapatkan bahwa mereka belum ada yang mengembangkan dan mengelola wakaf secara produktif hanya sebatas menjalankan amanah dari pewakif. saja seperti mendirikan masjid atau untuk tempat pemakaman dan baru sebagian harta wakaf yang memiliki Akta Ikrar Wakaf, sebagian lainnya belum ada, karena ketidaktahuan nazhir akan pentingnya Akta Ikrar Wakaf untuk melindungi harta wakaf. Selain itu nazhir juga belum mampu mengembangkan akta wakaf. Hal ini disebabkan karena kurangnya pemahaman nazhir tentang tatacara pengelolaan harta wakaf yang dapat memberikan manfaat sebagai sarana ibadah dan ekonomi yang bisa dirasakan oleh nazhir dan masyarakat secara luas. Hal ini disebabkan latar belakang pendidikannya nazhir di Kecamatan Kaur Utara Kabupaten Kaur rata-rata tamatan SD, menyebabkan informasi dan pengetahuan tentang pengelolaan wakaf masih kurang.

Selain itu nazhir yang ada di Kecamatan Kaur Utara tersebut yang menjadi penyebab mereka tidak paham tentang wakaf terutama tentang tugastugas mereka karena kurangnya sosialisasi dan pembinaan dari pihakpihak terkait seperti BWI ataupun KUA. Hal ini juga yang menjadi kendala mereka dalam melakukan pengelolaan harta wakaf, kendala lainnya yaitu kurangnya biaya untuk pengelolaan.

Kendala pengelolaan harta wakaf juga disebabkan karena kurangnya sosialisasi dari pihak terkait seperti KUA dan BWI. Menurut nazhir, KUA hanya melakukan sosialisasi sekali yang sifatnya hanya pendataan harta wakaf, tidak ada penjelasan yang berisi materi tentang prosedur perwakafan. Di KUA sendiri ada yang namanya Pejabat Pencatat Ikrar Wakaf (PPAIW) yang ditetapkan oleh menteri dan bertugas untuk membuat Akta Ikrar Wakaf.

PPAIW menurut Bab III UndangUndang Nomor 41 Tahun 2004 dalam Pasal 32 dan 33 bertugas melakukan pendaftaran harta benda wakaf:, dijelaskan dalam pasal 32 PPAIW atas nama nazhir mendaftarkan harta benda wakaf kepada istansi yang berwenang paling lambat 7 (tujuh) hari kerja sejak akta ikrar wakaf ditandatangani. Pasal 33 dalam pendaftaran harta benda wakaf 
sebagaimana dimaksud dalam Pasal 32

PPAIW menyerahkan: ${ }^{21}$

a. Salinan akta ikrar wakaf

b. Surat-surat dan/atau bukti-bukti kepemilikan dan dokumen terkait lainnya.

Namun dalam prakteknya PPAIW di KUA Kecamatan Kaur Utara belum maksimal dalam melaksanakan tugasnya tersebut terbukti dengan banyaknya harta wakaf yang belum memiliki Akta Ikrar Wakaf maupun yang sudah terdaftar di lembaga instansi yang berwenang seperti yang menjadi objek penelitian penulis. Padahal dari hasil pengamatan penulis bahwa harta benda wakaf terutama masjid, potensi pengelolaannya masih sangat besar karena dilihat dari tata letaknya masjid di Kecamatan Kaur Utara rata-rata berada dipinggir jalan raya, lahan disekitar masjid banyak yang masih luas dan masih bisa dikelola, dan daya dukung dari masyarakatnya juga cukup tinggi.

\section{E. KESIMPULAN}

Dari hasil penelitian dan analisa yang telah dilakukan oleh penulis maka diperoleh kesimpulkan sebagai berikut:

21 Undang-Undang Nomor 41 Tahun 2004 Tentang Wakaf (Pasal 32 dan 33)
1. Impelementasi tugas nazhir belum dilaksanakan secara maksimal sesuai amanah UU Nomor 41 Tahun 2004 yaitu melakukan pengadministrasian harta wakaf, mengelola dan mengembangkan harta wakaf, mengawasi dan menjaga harta wakaf serta melaporkan pelaksanaan tugasnya kepada Badan Wakaf Indonesia. dalam hal pengelolaan harta wakaf belum dilaksanakan. Dari ke 4 tugas tersebut hanya tugas melakukan pengadministrasian harta wakaf yang sudah diterapkan dan yang sudah menerapkan tugas pengadministrasian tersebut hanya 5 orang nazhir dari 18 orang nazhir yang ada.

2. Kendala nazhir dalam pengelolaan harta wakaf yaitu:

a. Kurangnya pemahaman dan pengetahuan nazhir tentang pengelolaan harta wakaf.

b. kurangnya pembinaan dan sosialisasi dari pihak-pihak terkait seperti Badan Wakaf Indonesia kepada nazhir serta Kantor Urusan Agama Kecamatan Kaur Utara Kabupaten Kaur.

c. Terkendalanya biaya pengelolaan sehingga nazhir tidak bisa mengelola harta wakaf yang dapat memberikan manfaat lebih untuk masyarakat. 


\section{DAFTAR PUSTAKA}

Ahmad Warson Munawir, Kamus AlMunawir Arab Indonesia, (Surabaya: Pustaka Progresif, 2002

Ali, Muhammad Daud, Sistem Ekonomi Islam: Zakat dan Wakaf ,(Jakarta: Universitas Indonesia, UI-Press, 2012

Direktorat Pengembangan Zakat dan Wakaf, Nazhir Profesional dan Amanah, Jakarta, Ikhlas Beramal, 2005

Effendi, Saekan Erniati, Kompilasi Hukum Islam di Indonesia, Surabaya, Arkola Offiset, 1997

Halim, Abdul, Hukum Perwakafan Di Indonesia, Jakarta, Ciputat Press, 2005

Harahap, Sumuran, Fiqh Wakaf, Jakarta, Dapertemen Agama Republik Indonesia, 2007

Haq, Faisal Haq, Wakaf dan Pewakafan di Indonesia, Pasuruan, Garoeda Indah, 1994

Irlianuddin.Kepala KUA Kecamatan Kaur Utara. Wawancara Tanggal 16 Oktober 2018

Muhammad Jawwad Mughniyah, Fiqh Lima Mazhab, Cet. Ke-I, Jakarta, Basrie Press, 1997

Manan, Abdul, Aneka Masalah Hukum Perdata Islam di Indonesia, cet.2, Jakarta, Kencana, 2008

Sugiyono, memahami Penelitian Kualitatif, Bandung, Alfabeta, 2014

Suparman, Usman, Perwakafan Di Indonesia , Serang, Darul Ulum Press, 1994

Undang-Undang Nomor 41 Tahun 2004 Tentang Wakaf 